\title{
Konaklama İşletmelerinde Stratejik Yönetim Süreci : Yöneticiler Üzerine Bir Araştırma
}

DOI: $10.26466 /$ opus.352676

\author{
Murat Türk $^{*} \underline{\text { Ergün Kara }}^{* *}$ \\ *Prof. Dr., Osmaniye Korkut Ata Üniversitesi, İ̈BF, Osmaniye/Türkiye \\ E-Posta: muratturk@osmaniye.edu.trＯRCID: 0000-0001-7040-4180 \\ ${ }^{* *}$ Dr., Muğla Sıtkı Koçman Üniversitesi, Marmaris Turizm Meslek Yüksekokulu, Muğla/Türkiye \\ E-Posta: erguncankara1@hotmail.comＯRCID: 0000-0002-7815-1111
}

\section{Öz}

Bu çalışmanın temel amacı, turizm sektöründe faaliyet gösteren konaklama işletmelerinde stratejik yönetim süreci ile ilgili işletme yöneticileri üzerine bir araştırma yapılmasıdır. Bu amaç doğrultusunda, araştırmanın kapsamın Marmaris İlçesi'nde faaliyet gösteren beş yıldızlı iki büyük konaklama işletmesinin orta ve üst düzey yöneticileri oluşturmaktadır. Çalışmada, veri toplama aracı olarak stratejik yönetim süreci anketi uygulanmıştır. Araştırma, ankete katılan işletmelerin orta ve üst düzey yöneticilerinin ölçme araçlarına kendilerini değerlendirme ile ilgili verdikleri cevaplarla sınırlandırılmıştır. Çalışma sonucunda, üzerinde araştırma yapılan iki büyük konaklama işletmesinde stratejik yönetim sürecinin başarılı bir şekilde yürütüldü̈̆̈̈ tespit edilmiştir. Ayrıca, orta ve üst düzey yöneticiler tarafindan işletmelere uygun stratejiler izlenmekte, değerlendirilmekte ve gerekli düzeltmelerin yapıldığı görülmektedir. Araştırmanın sonucunda işletme yöneticilerine yönelik olarak stratejik yönetim süreci ile ilgili çeşitli önerilerde bulunulmuştur.

Anahtar Kelimeler: Konaklama işletmeleri, stratejik yönetim, yöneticiler 


\title{
Strategic Management Process in Accomodation Business: A Study on Executives
}

DOI: $10.26466 /$ opus. 352676

\begin{abstract}
The main purpose of this study is to research on business executives about the strategic management process in accommodation business which operates in the tourism sector. In accordance with this purpose, mid-level and senior executives of two five star accommodation operations which operate in Marmaris district compose the scope of the research. Strategic management process survey was carried out as data collection tool in the study. The survey was limited to the answers related to selfassessment of mid-level and senior executives of firms which took part in survey. As a result of the study, it was determined that the strategic management process has been successfully carried out in the two major accommodation businesses that have been studied on. Also, it has been seen that strategies which are suitable for businesses are pursued and evaluated by mid-level and senior executives, and necessary corrections were made. As a result of the research, several suggestions were made about strategic management process for business executives.
\end{abstract}

Key Words : Accommodation business, strategic management, executives 


\section{Giriş}

Son yıllarda işletmeler tüm dünyada; küreselleşme, hızlı teknolojik değişim, yeni oluşan pazarlar, müşteri beklentilerinin değişmesi gibi nedenler sonucu ortaya çıkan ve her geçen gün giderek daha da ezici hale gelen yoğun rekabet karşısında daha stratejik düşünmek ve stratejik planlamayla stratejik karar almaya eskisinden daha fazla önem vermek zorunda kalmışlardır. Gerçekten de 1980'li yıllar öncesinde stratejik yönetim daha ziyade özel sektör alanında sadece çok uluslu şirketler, büyük holding ve şirketler tarafından bilinir ve uygulanırken, bugün çok sayıda işletme, stratejik yönetimi araç olarak kullanmaktadırlar (Özer, 2015, s. 70).

İşletmelerde stratejik yönetim süreci tepe yönetiminden alt kademelere doğru ilerlemektedir. Örgüt içerisinde stratejik kararları almak her ne kadar üst kademe yönetiminin sorumluluğu içerisinde olsa da, stratejilerin işletmenin iç ve dış çevresine uygulanmasında bölüm yöneticilerinden, diğer yönetici grupları ve hatta çalışanlara bile büyük görev düşmektedir. Eren'e (2005) göre stratejik yönetim; "stratejilerin planlanması için gerekli araştırma, inceleme, değerlendirme ve seçim çabalarını, planlanan bu stratejilerin uygulanabilmesi için örgüt içi her türlü yapısal ve motivasyonel tedbirlerin alınarak yürürlüğe konulmasını, daha sonra da kontrol edilmesini kapsayan ve işletmenin üst düzey kadrolarının faaliyetlerini ilgilendiren süreçler toplamıdır" (Uygur ve Bozkurt , 2017, s. 2). Stratejisi olmayan bir örgüt, önünü göremeyen ve yönü olmayan örgüttür. Günlük rutin çalışmalar, uygun ve ahenkli bir hedef oluşturamaz. Bu bağlamda söylenen şu söz stratejinin önemini vurgulamaktadır; "strateji, stratejik harekete rehberlik edecek planları, manevraları, modelleri, pozisyonları ve perspektifleri geliştirerek, bir örgüt için bir odak noktası, uyum ve ahenk ile amaç yaratmak için kullanılır" (Güçlü, 2003, s. 62).

Tüm organizasyonlarda olduğu gibi konaklama işletmelerinde de örgüt kaynakları temel olarak, beşeri, fiziksel, finansal ve bilgi/teknolojik içeriklidir. Bu kaynakların temel amaçlar etrafında optimum seviyede 
kullanılması bir çok nedenden dolayı zor şartlar altında çalışmayı zorunlu kılmaktadır. Turizm sektöründe mevcut iç ve dış faktörlerin hassas özellikleri işletmelerin uzun vadeli plan öngörülerinde sık sık değişiklik yapılmasını gerektirmektedir (Kaya, 2010, s.27).

\section{Konaklama İşletmelerinde Stratejik Yönetim Süreci}

Stratejik yönetim süreci, üst kademelerden başlayarak alt kademelere doğru hiyerarşik bir şekilde hareket eder. İşletmenin, tesisin yada bir kurumun stratejik yönünü kararlaştırmak üst kademe yönetiminin sorumluluğunda olmasına rağmen, iç ve diş çevre hakkında bilgiler, daha çok bölüm yöneticilerinden ve diğer yönetici gruplarından elde edilir. Eren'e göre stratejik yönetim; "stratejilerin planlanması için gerekli araştırma, inceleme, değerlendirme ve seçim çabalarını, planlanan bu stratejilerin uygulanabilmesi için örgüt içi her türlü yapısal ve motivasyonel tedbirlerin alınarak yürürlüğe konulmasını, daha sonra da kontrol edilmesini kapsayan ve işletmenin üst düzey kadrolarının faaliyetlerini ilgilendiren süreçler toplamıdır" (Güçlü, 2003, s. 6-77).

Stratejik yönetim süreci stratejik bilinçe sahip olmakla başlar. Stratejik bilinçlilik ise işletmelerde yöneticilerin (Ülgen ve Mirze,2013, s.57);

- İş dünyasının ve onun bir parçası olarak bulunduğu üst sistemin sürekli değişim içinde bulunduğunu,

- Sektördeki diğer işletmelerin ve rakiplerin değişen çevre koşullarına uygun çeşitli stratejiler ürettiğini ve uyguladığını,

- $\quad \mathrm{Bu}$ stratejilere cevap verebilecek ve hatta işletmeyi daha verimli bir duruma getirecek yeni stratejiler ve yeni fikirler üreterek çalışmalar yapmasını ifade etmektedir.

İşletmelerde stratejik bilincin oluşmasıyla birlikte uygulanma imkanı bulan stratejik yönetim sürecinin diğer basamaklarını; stratejistlerin 
seçilmesi ve görevlendirilmesi, stratejik analiz, stratejik yönlendirme, strateji oluşturma, stratejik uygulama ve stratejik kontrol aşaması oluşturur. Bu süreç elde edilen sonuçların kontrol edilmesinin ardından en başa dönülerek sürekli olarak tekrarlanan döngüsel bir süreci ifade etmektedir. Bu süreç, şekil 1'de genel bir çerçevede ifade edilmeye çalışılmıştır (Ödemiş, 2014, s.17-18).

\section{Şekil.1 Stratejik Yönetim Süreci}

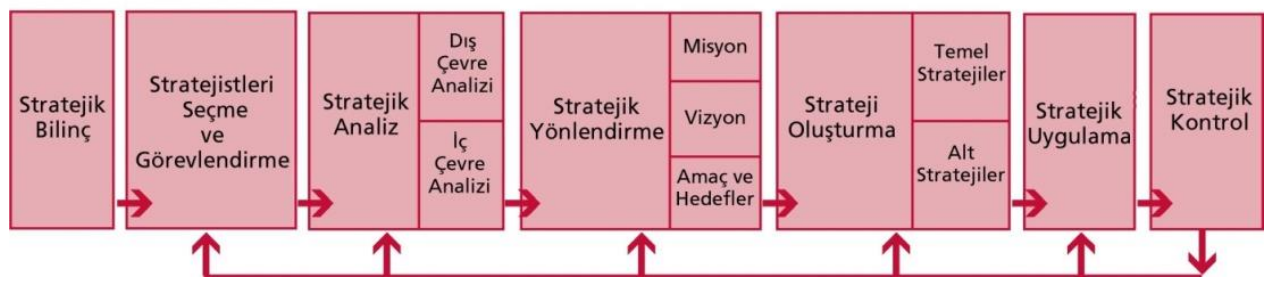

Kaynak: (Ülgen ve Mirze,2013, s.57).

Stratejik yönetim sürecininin evrelerini kısaca şöyle stralayabiliriz (Ülgen ve Mirze,2013, s. 57):

- Stratejistlerin seçimi ve görevlendirilmesi evresi

- Stratejik analiz evresi: Çevresel olanak ve sınırlamaların saptanması işletme dışı çevrenin (makro çevre ve sektör) analizi ve işletme içi çevrenin analizi, durum tespit matrislerinin hazırlanması,

- Stratejik yönlendirme evresi : Misyon, vizyon ve amaçların belirlenmesi,

- Strateji oluşturma evresi: Temel stratejiler ve alt stratejilerin, kurumsal, sektörel işlevsel stratejilerin belirlenmesi ve seçimi, bunların uygulanmasında kullanılacak tekniklerin belirlenmesi,

- Stratejik uygulama evresi: Stratejinin uygulama esnasındaki organizasyon yapısı, kullanılacak bilgi ve karar sistemleri, uygun liderlik anlayışı, kurum kültürü ve yönetim tarzları, 
- Stratejik kontrol evresi: Stratejilerin uygulanması sonucunda elde edilen performansın kontrolü ve kontrol süreci ile ilgili tekniklerdir.

Konaklama işletmelerinde plan yapmadan önce işletmeyi etkileyebilecek iç ve dış faktörler ile bunların değişim hızları konularında öngörüde bulunmak iki nedenden dolayı zorluk içermektedir: Birincisi, planlama çalışmalarında bulunacak kişilerin bilgi, tecrübe, yetenek ve deneyimlerinin yetersiz oluşu; ikincisi de, sektöre özgü mevsimsel değişkenlikler, fiyat değişiklikleri ve rekabet gibi nedenlerden dolayı talepteki belirsizliklerdir (Kıngır, 2006, s.462).

\subsection{Stratejik Bilinç}

Stratejik yönetim süreci ilk olarak stratejik bir bilince sahip olmakla başlamaktadır. Planlama sürecinde etkili olabilmek, rekabette başarılı olabilmek için gerekli değişikleri yapabilmek ve bu değişikliklerin hayata geçirilmesi için atılacak ilk adım, stratejik düşünmeyi sistematik olarak işletmenin tüm kademelerinde cesaretlendirmektir. Eğer bu aşama işletme içinde kabul edilebilir niteliğe gelir ve herkes tarafindan desteklenirse bundan sonraki aşamaların uygulanması daha kolay olacaktır. Bu nedenle öncelikle işletme çalışanlarına stratejik şekilde düşünüp karar almaları benimsetilmelidir (Şentürk, 2010, s.13).

Bu noktada ancak stratejik bir bilince sahip yöneticiler tarafindan başarılı bir şekilde uygulanabilecek ve işletmeleri parlak bir geleceğe taşıyabilecek stratejik yönetim anlayışının uygulama sürecinde yer alacak stratejistlerin doğru kişiler arasından seçilmesi ve görevlendirilmesi, esasında stratejik yönetim sürecinin en önemli ve kritik aşamalarındandır (Ödemiş, 2014, s.20). 


\subsection{Stratejistleri Seçme ve Görevlendirme}

Stratejik yönetim sürecini başlatan, bu sürecin uygulanmasını sağlayan ve her aşamasında etkin bir rol üstlenen stratejik faaliyetlerden sorumlu olan görevlilere stratejist denmektedir. Bu stratejistler söz konusu konularda işletme içinden ya da dışından seçilenlerin yanında profesyonel olarak işletmelerde sorumlu ve görevli olarak çalışan stratejistlerden oluşmaktadır. Dolayısıyla işletmelerde stratejik yönetim sürecinin uygulanmasinda üst, orta ve alt yönetim düzeyinde yönetici olsun ya da olmasın fiilen görev yapan kişiler stratejist olarak isimlendirilirler (Ülgen ve Mirze, 2013, s.60).

\subsection{Stratejik Analiz}

Stratejik yönetim sürecinin en önemli aşaması olan stratejik analiz evresi, işletmenin mevcut durumunu görebilmesine ve işletmeyi etkileyen tüm unsurların değerlendirilmesine olanak vermektedir. Dolayısıyla stratejik analiz süreci, işletmenin çevresinin ve tüm işletme faaliyetlerinin analiz edilmesiyle ilgili bir süreçtir. Stratejik analiz, amaçların tanımlanması, bunlara uygun stratejilerin seçilmesi ve işletmenin iç ve dış çevresinin incelenmesine yönelik faaliyetleri kapsamaktadır. Ekonomik, sosyokültürel ve teknolojik açıdan sürekli değişen bir rekabet ortamında işletmeler kendilerinin güçlü ve zayıf yönlerini belirleyerek, diş tehditlerden en az maliyetle kurtulmayı ve firsatlardan da maksimum faydayı sağlayacak stratejileri geliştirmeyi, bu analizlerin sağlıklı bir şekilde yapılıp değerlendirilmesi ile sağlayacaklardır (Çıkmak, 2012, s.13).

\subsubsection{SWOT Analizi ve Planlama}

Konaklama işletmelerinin stratejik yönetim sürecinde ilk olarak SWOT analizini uygulamaları gerekmektedir. SWOT analizi herhangi bir ürünün 
rakiplerine karşı avantaj ve dezavantajlarını ortaya koyarak işletmenin bu ürünle karşılaşabileceği fırsat ve tehditlerin önceden belirlenmesini, işletmenin zayıf ve güçlü yanlarının ortaya konmasına yarayan bir tekniktir. $\mathrm{Bu}$ analiz sonucu elde edilen veriler, saha sonra stratejik planlamada değerlendirilmektedir (Güngör ve Arslan,2004,s. 68). SWOT kelimesi İngilizce dört kelimenin baş harflerinden oluşmaktadır (S/Strenghts=Güçlü Yönler, W/Weaknesses=Zayıf Yönler, O/Opportunities=Firsatlar, $\mathrm{T} /$ Threats $=$ Tehditler).

Turizm sektöründe faaliyet gösteren bir konaklama işletmesinin muhtemel bir SWOT analizi tablo 1'de ifade edilerek genel hatlarıyla şu konuları kapsayacaktır (Şişman, 2007):

\section{Tablo 1. Konaklama İsletmesinin SWOT Analizi}

\begin{tabular}{|c|c|}
\hline $\begin{array}{l}\text { Konaklama İşletmelerinin Güçlü ve } \\
\text { Zayıf Yönleri }\end{array}$ & İşletme Dışı Tehdit ve Fursatlar \\
\hline -İşletmenin kapasitesi ve donanımı & -İşletmenin kuruluş yeri, ulaşım im- \\
\hline •Personel ve yöneticilerin eğitimi & kanları ve çeşitli merkezlere uzaklığı \\
\hline •Personel tedariki & •Rakip işletmelerin durumu \\
\hline $\begin{array}{l}\text { •Müşterilere sunulan ürün ve hizmetlerin } \\
\text { çeşitliliği/kalitesi }\end{array}$ & $\begin{array}{l}\text {-Bölgenin ekonomik, sosyal ve kültü- } \\
\text { rel durumu }\end{array}$ \\
\hline •İşletmedeki sağlık ve hijyenik koşullar & •Teknolojik gelişmeler \\
\hline -Kontrol ve denetimlerin nasıl sağlandığı & -Yerel etkinlik ve olaylar \\
\hline •Maliyetler & -Merkezi ve yerel kamu yöne- \\
\hline •Güvenlik & timlerinin turizm politikaları \\
\hline -Beklenmeyen olaylara karşı hazırlık & •Bölgenin alt ve üst yapısı \\
\hline (yangin, deprem, sel vb) & -Turizm sektöründe ülke ve bölge \\
\hline -Ekonomik ve finansal krizlere karşı & düzeyindeki gelişmeler \\
\hline hazırlik & •Mevsimsel faktörler \\
\hline •İşletme içi iletişim & •Küresel ölçekli gelişmeler \\
\hline
\end{tabular}

Kaynak: Şişman, 2007

$\mathrm{Bu}$ analizler yapıldıktan sonra, elde edilen veriler doğrultusunda konaklama işletmelerinin uygulayacakları stratejilere göre planlama yapmaları gerekmektedir. Planlar yapılırken, bu planları etkileyen faktörlerin zaman içerisinde hem içerik hem de etki ve önem derecesi olarak 
değişeceği göz önünde tutulmalıdır. Örneğin, tablo 2'de görüleceği üzere, iş amaçlı seyahatlerde bir otelin tercih edilmesinde önemli olan faktörler bugün ve gelecekte farklı olacaktır. Bu durumda, müşteri profilinin çoğunlukla iş amaçlı seyahat edenlerden oluştuğu bir otel işletmesinin oda planlamasında ve dizaynında en çok önem verdiği kriter odaların sessiz olması iken, gelecekteki en önemli kriter ise odaların yüksek teknolojik ürün, iş ve iletişim olanaklarına sahip olması olacaktır. Bu durumda planların daima revize edilerek stratejik yönetim sürecine uyumlu hale getirilmesi gerekecektir (Kaya, 2010, s. 27-35).

Tablo 2. İş Seyahatlerinde Bir Otelin Bugün ve Gelecekte Tercih Edilmesinde Önemli Olan/Olacak Faktörler

\begin{tabular}{llll}
\hline $\begin{array}{l}\text { Önem } \\
\text { Sırası }\end{array}$ & $\begin{array}{l}\text { Günümüzde Etkili Olan } \\
\text { Faktörler }\end{array}$ & $\begin{array}{l}\text { Önem } \\
\text { Sırası }\end{array}$ & $\begin{array}{l}\text { Gelecek Etkili Olacak } \\
\text { Faktörler }\end{array}$ \\
\hline 1 & Sessiz oda & 1 & $\begin{array}{l}\text { Yüksek teknolojik ürün, iş ve iletişi } \\
\text { olanakları }\end{array}$ \\
2 & Tam temizlik & 2 & Güvenli yer \\
3 & Isı ve nem kontrolü & 3 & Sigara içilmeyen odalar \\
4 & Yüksek güvenlik standartları & 4 & Yüksek güvenlik standartları \\
5 & Güvenli yer & 5 & Etkin mesaj servisi \\
6 & Etkin mesaj servisi & 6 & Tam temizlik \\
7 & Sigara içilmeyen odalar & 7 & Sessiz oda \\
8 & Şehir merkezine yakınlık & 8 & Uçuş mili kazanma fırsatları \\
9 & Herşey dahil konaklama & 9 & Isı ve nem kontrolü \\
10 & Çevre temizliği & 10 & Çevreci anlayışa sahip olma \\
\hline \hline
\end{tabular}

Kaynak: Fache, 2000:358. 


\subsection{Stratejik Yönlendirme}

Stratejik yönlendirme evresi, işletmenin misyon, vizyon amaç ve hedeflerinin belirlenmesi olarak ifade edilmektedir.

\subsection{Strateji Oluşturma Evresi}

Strateji geliştirme veya formüle etme aşaması (oluşturma), çevresel analizlerden elde edilen bulgulardan hareketle rekabetçi avantaja sahip olmasını veya mevcut avantajını koruyabilmesini sağlayacak uzun vadeli planların geliştirilmesini ifade etmektedir. Bu aşamada örgütün misyonunu, hedef ve stratejileri belirlenmekte ve faaliyetlerde izlenecek politikalar geliştirilmektedir. Alternatif stratejilerin ortaya çıkması ve stratejik hedeflerine en iyi şekilde ulaşılmasını sağlayacak olanakların seçilmesi için örgütün misyon, vizyon, hedef, politika ve iç/dış çevre hakkındaki bilgilerin dikkate alınması gerekmektedir (Özer, 2011, s. 277). Sonra belirlenen stratejilerin seçimi için kullanılacak seçim kriterleri belirlenir ve alternatif stratejiler arasından en uygun seçim yapılır.

\subsection{Stratejik Uygulama ve Kontrol}

Stratejiler geliştirildikten sonra üst yönetimin sorumluluğunda orta ve alt yönetim kademeleri ile işbirliğine gidilerek aksiyon planlarının uygulanmasına geçilir. Stratejik uygulama evresinde stratejilere uygun örgütsel yapının kurulması ve tüm kaynaklar ile sistemlerin harekete geçirilmesi, stratejileri yerine getirebilecek nitelikte insan kaynaklarının seçim, eğitilmesi ve bunlara uygun yönetim birimlerinin ve liderlerinin seçimi ile uygun örgütsel iklim ortamının hazırlanması gerekmektedir (Ülgen ve Mirze, 2013).

Başarılı bir stratejik kontrol işletmenin çeşitli foksiyonlarının performansı ve standartlara uygunluğu ile ilgili geçerli, güncel ve güvenilir 
enformasyon gerektirmektedir. MIS (Management Information SystemsYönetim Bilgi Sistemi) adı verilen bu yapının yeterli düzeyde bilgi sağlayıp sağlamadığı yöneticiler tarafından test edilmelidir (Kutlu, 2010). Konaklama işletmelerinde özellikle önbüro-kat hizmetleri otomasyon sistemlerinde elde edilen rezervasyon bilgileri işletmelerin gelecekteki muhtemel gelir ve gider projeksiyonlarına 1şık tutacağı için finansal stratejilerin kontrol edilmesinde önemli bir rol oynamaktadır. İşletmelerde kontrol geriye yönelik, ileriye yönelik ya da eş zamanlı olarak üç farklı şekilde yapılabilir. Her üç yaklaşımda da kontrol evreleri şunlardan oluşmaktadır (Ülgen ve Mirze, 2013):

- Standartların oluşturulması,

- Mevcut durumun ölçülmesi ve belirlenmesi,

- Standartlarla mevcut durumun karşılaştırılması ve varsa sapmaların belirlenmesi ve yorumlanması,

- Gerekli düzeltmelerin yapılmasıdır.

Konaklama işletmelerinde üretim ve tüketimin aynı anda gerçekleşmesi eş zamanlı kontrol kontrol yaklaşımını diğer yaklaşımlara göre daha önemli kılmaktadır. Özellikle ön büro departmanı ile yiyecek-içecek ve kat hizmetleri departmanları arasında eş zamanlı bilgi akışı ve bilgilerin kontrolü diğer departmanlara kıyasla daha büyük önem taşımaktadır. Zira, başta kat hizmetleri ile yiyecek-içecek departmanları olmak üzere tüm departmanlar özellikle önbüro departmanından gelecek olan konaklama verilerine göre faaliyetlerini yönlendirmektedir (örneğin; mutfakta hazırlanarak servis edilecek olan yiyecek içecek miktarı, temizlenecek oda sayıları). Bu nedenden dolayı konaklama işletmelerinde diğer alt departmanların aksiyon planlarının uygulanmasının ve kontrollerinin özellikle önbüro departmanının plan ve faaliyetleri ile koordineli bir şekilde gerçekleşmesi gerekmektedir. Bu noktada önbüro departmanında uygulanan manuel ya da otomasyona dayalı sistemlerin işletme yapısına uygun olarak seçilmesi gerekir (Kaya,2010, s. 33). 
Stratejik kontrol süreci, işletmenin bütününü kapsayan bir kontrol sisteminin tasarlanması ve kurulması, seçilmiş uzun vadeli faaliyetlerin takip edilmesi ve bu tür faaliyetlerle ilgili programların gözden geçirilerek düzeltilmesi demektir. Stratejik değerlendirme ve kontrol süreci dört safhadan meydana gelmektedir (Dinçer,2004, s.376):

- Başarı standartlarının belirlenmesi,

- Uygulama sonuçlarının ve başarılarının ölçülmesi,

- Standartlarla gerçekleşen sonuçların karşılaştırılması,

- Problemlerin çözümü ve düzeltici tedbirlerin alınmasıdır.

İşletmelerdeki kontrol işlevi geriye doğru kontrol, ileriye doğru kontrol ve eşzamanlı kontrol olmak üzere üç şekilde gerçekleştirilebilir (Akgemci,2008, s.40-41):

1. Geriye yönelik (feedback) kontrol: Yapılan işler ve faaliyetler tamamlandıktan sonrayapılan kontroller bu isimle adlandırılır.

2. İleriye yönelik (feedforward) kontrol: İşlerin ve faaliyetlerin gerçekleşmesinden önce kullanılacak girdilerin kontrol edilerek, faaliyet esnasında oluşabilecek hataların ve yanlış uygulamaların önlenmesine yönelik bir kontrol yöntemidir.

3. Eşzamanlı (concurrent) kontrol: Daha çok sürekli yapılan ve sonuçları zaman alan işlerde; birbirini izleme ve karşlıklı bağımlılık ilişkisi bulunan faaliyetler sürerken, faaliyetlerin her aşamasında belirli noktalarda kontrol yapılmasıdır.

\section{YÖNTEM}

Bu bölümde araştırmanın amacı, önemi, kapsamı, veri toplama araçları ve araştırma bulgularına yer verilmiştir. 


\subsection{Araştırmanın Amacı ve Önemi}

$\mathrm{Bu}$ çalışma, turizm sektöründe faaliyet gösteren konaklama işletmelerinde stratejik yönetim süreci ile ilgili işletme yöneticileri üzerine bir araştırma yapılmasıdır. Bu amaç doğrultusunda, araştırmanın kapsamını Marmaris İlçesi'nde faaliyet gösteren beş yıldızlı iki büyük konaklama işletmesinin orta ve üst düzey yöneticileri oluşturmaktadır. Çalışmada, veri toplama aracı olarak stratejik yönetim süreci anketi uygulanmıştır. Literatürde konaklama işletmelerinde stratejik yönetim ile ilgili olarak kaynakların sınırlı olması, işletme yöneticilerinin stratejik yönetim ile ilgili algılarını diğer sektörlerdeki mevcut uygulamalar ve ilgili genel bilgilerle sınırlandırmaktadır (Kaya, 2010, s. 33). Ayrıca yapılan çalışmayla stratejik yönetimin en temel unsuru olan stratejik planlamanın konaklama işletmeleri açısından önemi ve gerekliliği ortaya konularak bu konuda sınırlı olan literatüre katkı sağlanması hedeflenmiştir.

\subsection{Araştırmanın Kapsamı (Evren ve Örneklemi)}

Araştırmanın evrenini turizm sektörü çerçevesinde Muğla ili Marmaris İlçesi'nde faaliyette bulunan 31 adet beş yıldızlı konaklama işletmesi oluşturmaktadır. Örneklemi ise üzerinde araştırma yapılan beş yıldızlı iki büyük konaklama işletmesi oluşturmaktadır. Dolayısıyla bu araştırmanın örneklemini konaklama işletmelerinde orta ve üst düzey yönetici olarak görev yapan kişilerdir. Bu araştırma kapsamında tesislerin orta ve üst düzey olmak üzere toplam 25 yönetici ile görüşmeler gerçekleştirilmiştir. $\mathrm{Bu}$ araştırmada elde edilen veriler yalnızca bu araştırmaya konu olan iki büyük konaklama işletmesi için geçerli olup, bu işletmelerin özelinde sınırlandırılmıştır.

\subsection{Veri Toplama Teknikleri}


Marmaris İlçesi'nde faaliyet gösteren iki büyük konaklama işletmesi üzerinde gerçekleştirilen araştırmada Association Management Consulting \& Evaluation Services (AMCES,2016) tarafından geliştirilen stratejik yönetim ölçeği kullanılmıştır. Katılımcılardan soruları 1-10 değerleri arasında bir puan vermeleri istenmiştir. Verilen değerler Microsoft excel programı ve SPSS 22,0 For Windows istatistiki paket programında ortalaması alınmış ve yüzde değerler olarak ifade edilmiştir. Stratejik yönetim süreci ile ilgili üzerinde araştırma yapılan işletmelerde orta ve üst kademede görev yapan toplam 25 yöneticinin tamamına ulaşılmış ve araştırma için yeterli sonuç elde edilmiştir.

Tablo 3. Katılımcıların Yönetsel Pozisyonlarına Göre Dağılımı

\begin{tabular}{lll}
\hline Düzey & Yönetsel Pozisyon & Kişi Sayısı (n) \\
\hline Üst Düzey & Genel Müdür & 2 \\
\hline & İnsan Kaynakları Müdürü & 3 \\
& Muhasebe Müdürü & 2 \\
& Ön Büro Müdürü & 3 \\
& Satış ve Pazarlama Müdürü & 2 \\
& Yiyecek \& İçecek Müdürü & 2 \\
Orta Düzey & Teknik Müdür & 2 \\
& Halkla İlişkiler Müdürü & 2 \\
& Kat Hizmetleri Müdürü & 2 \\
& Mutfak Sorumlusu & 2 \\
& Güvenlik Müdürü & 2 \\
& Satın Alma Müdürü & 1 \\
\cline { 2 - 3 } & Toplam & 25 \\
\hline
\end{tabular}

\subsection{Bulgular}

Uygulamada stratejik yönetim sürecinin stratejik bilinç, stratejistleri seçme ve görevlendirme, stratejik analiz, stratejik yönlendirme ve strateji oluşturma evresi birinci alt bölüm stratejik formülasyon başlığı altında katılımcılar tarafından değerlendirilmesi istenmiş ve sonuçlar 
açıklanmıştır. Stratejilerin uygulanması ise ikinci bölümü oluşturmaktadır. Üçüncü bölümde ise stratejilerin kontrolüdür. Bu doğrultuda elde edilen sonuçlar aşağıda Tablo 4 yardımıyla açıklanmıştır (Uygur ve Bozkurt, 2017).

Tablo 4. Katılımcıların Stratejik Formülasyon Dağılımı Sonuçları

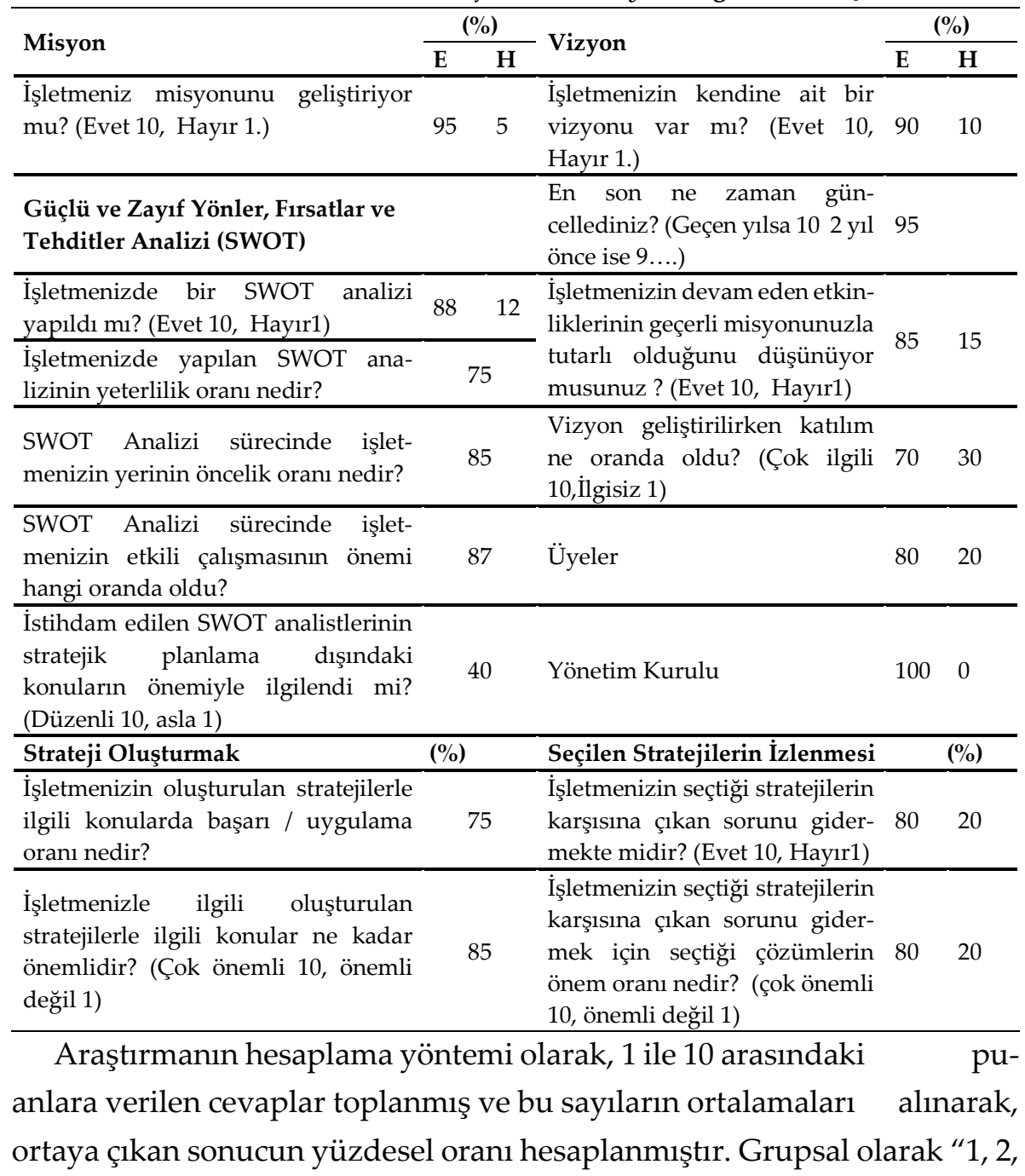


3" cevabı hayır veya olumsuz, "4, 5, 6" cevapları kararsız ve "7, 8, 9 ile 10" cevapları ise evet veya olumlu olarak değerlendirilmiştir.

Tablo 4 incelendiğinde katılımcılara yöneltilen "İşletmeniz misyonunu geliştiriyor mu?" sorusuna katılımcıların \% 95'i evet cevabı verilmiştir. Yine katılımcların \% 90'ı işletmelerine ait bit vizyon olduğunu belirtmişlerdir. Vizyon konusunda görüş bildirenlerin \% 95'i işletme vizyonunun yakın bir zamanda güncellendiğini, \%85'i işletmenin mevcut vizyonunun misyon hedefleri ile doğru orantılı olduğunu ve bu hedefler doğrultusunda oluşturulduğunu, işletmelerin vizyonunun belirlenmesinde çalışanların, yöneticilerin ve üyelerin \% 80'nin, yönetim kurulunun ise \%100'nün katılımı ve desteği ile oluşturulduğu belirtilmiştir. Yine anketin, işletmelerin güçlü ve zayıf yönlerinin değerlendirildiği (SWOT) analiz kısmında; yöneticilerin \%88'i işletmelerinde SWOT analizinin yapıldığını, \%75'i yapılan SWOT analizinin yeterli olduğunu, \%85'i SWOT analizindeki önceliğin işletmeleri olduğunu, \%87'si işletme faaliyetlerinin SWOT analizi doğrultusunda gerçekleştirildiğini belirtmişlerdir.

İşletmelerin birçoğunda analist istihdam edilmediği için "İstihdam edilen SWOT analistlerinin stratejik planlama dışındaki konuların önemiyle ilgilendi mi?" sorusu \% 40 ile hayır olarak nitelendirmiştir. İşletmelerde, oluşturulan stratejilerin uygulanması konusunda araştırmaya katılanların \% 75'i işletmelerini başarılı bulduklarını, \% 85'i stratejiler oluşturulurken işletmenin misyon ve vizyonu doğrultusunda şekillendirildiğini, \% 80'i uygulanan stratejilerin işletmenin karşılaştığı sorunları gidermede başarılı olduğunu ve "İşletmenizin seçtiği stratejilerin karşısına çıkan sorunu gidermek için seçtiği çözümlerin önem oranı nedir?" sorusuna katılımcıların \% 80'inin cevabıyla stratejilerin sorun çözmede çok önemli olduğu anlaşılmaktadır. 


\begin{tabular}{|c|c|c|c|}
\hline \multirow{2}{*}{ Politika Desteği } & $(\%)$ & \multirow[t]{2}{*}{ Finansal Kapasite } & \multirow[t]{2}{*}{$(\%)$} \\
\hline & E $\quad \mathrm{H}$ & & \\
\hline $\begin{array}{l}\text { Şirketinizin ana politika el kitabı var } \\
\text { mıdır? (Evet 10, Hayır } 1 \text { ) }\end{array}$ & 60 & $\begin{array}{l}\text { Şirketinizin uyguladığ1 } \\
\text { stratejilerin finansal kapa- } \\
\text { sitesinin oranı nedir? } \\
\end{array}$ & 70 \\
\hline $\begin{array}{l}\text { Şirket politikanız düzenli olarak gün- } \\
\text { cellendi mi? (Geçen yılsa 10, } 2 \text { yıl } \\
\text { önce ise } 9 \mathrm{vb} \text {.) }\end{array}$ & 75 & $\begin{array}{l}\text { Stratejik girişimlerin uy- } \\
\text { gulanmasını desteklemek } \\
\text { için taahhüt edilen fi- } \\
\text { nansal kaynağın oranı } \\
\text { nedir? }\end{array}$ & 65 \\
\hline $\begin{array}{l}\text { Şirket politikanızın şirket etkinlikler- } \\
\text { ine uygunluk oranı nedir? (Çok uy- } \\
\text { gun 10,Uygun değil 1) }\end{array}$ & 90 & Üyeler tarafından & 75 \\
\hline $\begin{array}{l}\text { Şirket politikanızın geliştirilmesinin } \\
\text { ve uygulanmasının, desteklenme ve } \\
\text { anlaşılma oranı nasıldır? }\end{array}$ & 90 & $\begin{array}{l}\text { Yönetim Kurulu tarafın- } \\
\text { dan }\end{array}$ & 85 \\
\hline Üyeler tarafından & 90 & İnsan Kaynakları & $\begin{array}{c}\text { Yüzde } \\
(\%)\end{array}$ \\
\hline Yönetim Kurulu tarafından & 100 & \begin{tabular}{ll}
\multicolumn{3}{l}{ Yeni stratejilerin yönetimi } \\
yâda bir değişim sürecini \\
uygulayacak ve yöne- \\
tecek yetenekteki & insan \\
kaynaklarının & oranı \\
nedir? & \\
\end{tabular} & 95 \\
\hline Yetkili Müdür & 100 & Üyeler tarafından & 95 \\
\hline Organizasyon Alt Yapısı & $\begin{array}{c}\text { Yüzde } \\
\text { (\%) }\end{array}$ & $\begin{array}{l}\text { Yönetim Kurulu tarafın- } \\
\text { dan }\end{array}$ & 100 \\
\hline $\begin{array}{l}\text { Şirketinizin mevcut altyapısının } \\
\text { stratejik girişimlerin uygulanmasına } \\
\text { desteğinin uygunluk oranı nedir? (10 } \\
\text { çok uygun, uygun değil 1) }\end{array}$ & 90 & $\begin{array}{l}\text { Şirket personelinin } \\
\text { stratejik girişimlerin uy- } \\
\text { gulanması ve yönetimin- } \\
\text { deki yeterlilik oranı } \\
\text { nedir? }\end{array}$ & 95 \\
\hline
\end{tabular}

Stratejik girişimlerin uygulanmasıyla ilgili mevcut yönetim modelinizin etkinlik oranı nedir?(çok etkili model 10, etkisiz 1)

İşletme stratejisi uygulama konusundaki anket sorularının analizine göre tablo 5'e bakıldığında; "Şirketinizin ana politika el kitabı var mıdır?" sorusuna yöneticilerin \% 60'ı işletme politikaları konunsa bir el kitaplarının bulunduğunu,"Şirket politikanız düzenli olarak güncellendi mi?" sorusuna \% 75 oranında evet cevabı verildiği, \% 90'ı şirket politikalarını 
şirket etkinlikleri doğrusunda belirlendiğini ve oluşturulduğunu, işletme politikalarının anlaşılma ve uygulama desteğinin yönetim kurulu ve üst yönetim tarafindan \% 100 olarak, diğer orta kademe yönetici ve çalışanlar için söz konusu desteğin \% 80 civarında olduğu belirtilmiştir. Organizasyon alt yapısına yönelik olarak yöneltilen "Şirketinizin mevcut altyapısının stratejik girişimlerin uygulanmasına desteğinin uygunluk oranı nedir ?" sorusuna \% 90 oranında çok uygun olduğu, ankete katılanların tamamı, işletmelerindeki yönetim modelinin, stratejik girişim ve uygulamalarda çok etkili olduğunu, \% 70'i şirketin finansal kapasitesinin büyük kısmının işletmenin stratejileri doğrultusunda kullanıldığını, yine strateji uygulamak için işletmeler tarafindan öngörülen kaynak gereksiniminin \% 65 olduğu belirtilmiştir. İnsan kaynakları konusunda katılımcılara yöneltilen "Yeni stratejilerin yönetimi yâda bir değişim sürecini uygulayacak ve yönetecek yetenekteki insan kaynaklarının oranı nedir?" sorusuna \% 95 oranında olumlu, "Şirket personelinin stratejik girişimlerin uygulanması ve yönetimindeki yeterlilik oranı nedir?" sorusuna \% 95 oranında olumlu cevap vererek, işletmelerindeki insan kaynakları ve yönetim şekline güvendiklerini ortaya koymuşlardır.

Tablo 6. Katılımcıların Strateji Değerlendirme Dağılımı Sonuçları

\begin{tabular}{|c|c|c|c|c|}
\hline \multirow{2}{*}{ Performans Ölçümü } & \multicolumn{2}{|c|}{ Yüzde (\%) } & \multirow{2}{*}{$\begin{array}{l}\text { Değişim/ Katılım Etkilerinin } \\
\text { İncelenmesi }\end{array}$} & \multirow{2}{*}{$\begin{array}{l}\text { Yüzde } \\
(\%)\end{array}$} \\
\hline & $\mathbf{E}$ & $\mathbf{H}$ & & \\
\hline \multirow{3}{*}{$\begin{array}{l}\text { Şirketinizin stratejik girişimlerinin } \\
\text { gelişmesi, bir dizi temel perfor- } \\
\text { mans göstergelerinden mi ya da } \\
\text { bazıları tarafından başarılan } \\
\text { sorumluluktan mıdır? (temel per- } \\
\text { formans göstergeleri } 10 \text {, temel per- } \\
\text { formans göstergeleri yok } 1 \text { ) }\end{array}$} & \multirow[t]{3}{*}{85} & \multirow[t]{3}{*}{15} & $\begin{array}{l}\text { Şirketiniz etkili bir değer- } \\
\text { lendirmeden sonraki stratejik } \\
\text { girişimlerin formülasyonunu } \\
\text { değiştirme oranı nedir? }\end{array}$ & 85 \\
\hline & & & $\begin{array}{l}\text { Stratejik değerlendirmelere } \\
\text { katılım oranı nedir? }\end{array}$ & 90 \\
\hline & & & Yönetim Kurulunun & 100 \\
\hline \multirow[b]{2}{*}{$\begin{array}{l}\text { Şirketinizin devam eden stratejik } \\
\text { girişimlerle ilgili uygulamaları } \\
\text { değerlendirme oranı nedir? } \\
\text { (Düzenli olarak büyük bir iş gibi } \\
\text { yapılmaktadır 10, Değerlendirme } \\
\text { oluşturmaz 1) }\end{array}$} & \multirow[b]{2}{*}{95} & \multirow[b]{2}{*}{5} & Yetkili Müdürün & 100 \\
\hline & & & İnsan Kaynakları Müdürü & 100 \\
\hline
\end{tabular}


Tablo 6'deki bilgilere bakıldığında, katılımcıların strateji değerlendirme dağılımı sonuçları konusunda performans ölçümüne yönelik sorulan "Şirketinizin stratejik girişimlerinin gelişmesi, bir dizi temel performans göstergelerinden mi ya da bazıları tarafından başarılan sorumluluktan mıdır?" sorusuna \% 85 oranında stratejik uygulama ve başarının işletmenin genel performansından kaynaklandığı, \% 95'ine göre işletmelerdeki stratejik girişimlerin belli bir düzen ve plan içerisinde yürütüldüğü, şirketin etkili bir değerlendirmeden sonraki stratejik girişimlerin formülasyonunu değiştirme oranının \% 85 olduğu ve stratejik değerlendirmeye işletmenin en üst yönetiminden en alt çalışanına kadar \% 100 katılımın sağlandığı ankete verilen cevaplardan anlaşılmıştır.

\section{Sonuç}

Stratejik yönetim süreci turizm sektöründe faaliyet gösteren konaklama işletmelerinin gelecekteki belirsizliklere karşı daha iyi pozisyon alabilmeleri açısından son derece önemli bir kavramdır. Çünkü turizm sektöründe yer alan konaklama işletmelerinde başarılı bir stratejik yönetim sürecinin uygulanması hem iç ve dış fırsatların daha iyi değerlendirilmesine hem de tehditlerin bertaraf edilmesi için daha uygun tedbirlerin alınmasına yardımcı olmaktadır. Konaklama işletmelerinin başta talep olmak üzere son derece belirsiz ve değişken parametrelere sahip olmakla birlikte hizmet sektörü olması nedeniyle bu işletmelerin uzun dönemde tek bir strateji üzerinde odaklanmalarını zorlaştırmaktadır

Yapılan analizler sonucunda, Marmaris İlçesi'nde faaliyet gösteren beş yıldızlı iki büyük konaklama işletmesinin kendine ait bir misyonu ve vizyonunun olduğu tespit edilmiştir. Bu tesislerde görev yapan orta ve üst düzey yöneticiler işletmeye ait vizyonu geliştirerek ilerlettiği ve bunu ise geçen son bir yıl içerisinde gerçekleştirdiği sonucuna ulaşılmıştır. İşletme vizyonu oluşturulurken üyelerin işletme faaliyet ve etkinlik alanına göre hazırlandığ1 ve yönetim kurulunun ise üyelere göre vizyon belirlemede 
daha baskın olduğu görülmektedir. Konaklama işletmelerinin son bir kaç yıl içerisinde SWOT analizi yaptırdığı ve SWOT analizinin yeterliliğinin ise orta düzey ile üst düzey arasında olduğu ifade edilmiştir. SWOT analizi yapılırken konaklama işletmelerinin faaliyet gösterdiği yer ve konum dışı hususlara önem verilmesi stratejik yönetim süreci açısından işletmelerin genel durum değerlendirmesine önem verdiğini göstermektedir. Strateji oluşturma aşamasında ise konaklama işletmeleri oluşturulan stratejilerin mevcut işletmelerin ilgilendiği konulara ve yapısına uygun olduğunu ve stratejik açıdan uygulama oranının yüksek olduğunu ifade etmişlerdir. Daha sonraki aşamalarda stratejiler izlenmekte ve karşılaşılan sorunları çözmede uygulanan stratejilerin başarılı olduğu düşünülmektedir.

Stratejik yönetim sürecinde yer alan en önemli evrelerden bir tanesi de stratejilerin uygulanması evresidir. Konaklama işletmeleri kendilerine ait bir örgüt el kitabının var olduğunu, bunun sürekli güncellendiğini ve işletme politikaları ile çok uyumlu ve uygun olduğunu ifa etmişlerdir. Üyeler, yönetim kurulu ve yetkili müdürler tarafından konaklama işletmesinin politikalarının geliştirilme ve uygulanma, desteklenme ve anlaşılma oranının çok yüksek olduğu ifade etmişlerdir. İşletmelerin finansal kapasitesinin orta düzey ile üst düzey arasında olduğu ve stratejik girişimlerin uygulanmasını desteklemek için üyeler ve yönetim kurulu tarafından taahhüt edilen finansal kaynak oranın ise yüksek düzeyde desteklendiği tespit edilmiştir. Stratejik kararlar uygulanmakta ve desteklenmekte olup ayrıca organizasyon altyapısı stratejik girişimleri yüksek düzeyde desteklemektedir. İki konaklama işletmesi orta ve üst düzey yönetimi, uygulanan stratejik yönetim modelinin etkinlik oranının çok yüksek olduğunu ifade etmiştir. İnsan kaynaklarının değişime ve yeni stratejik uygulamalara hazır olduğu hem üyeler hem de yönetim kurulu tarafından ifade edilmiştir.

Stratejilerin uygulanması evresinden sonra gelen bir diğer evre ise uygulanan stratejilerin değerlendirilmesi evresidir. Üzerinde araştırma 
yapılan konaklama işletmeleri stratejik girişimlerinin gelişmesi için bir dizi performans göstergelerinden faydalandı̆̆ını ve işletmelerin devam eden stratejik girişimlerle ilgili uygulamaları değerlendirme oranının ise çok yüksek düzeyde olduğunu ifade etmiştir. Etkili bir formülasyon meydana gelmediyse işletme buna müdahale etmekte ve stratejiyi değiştirmektedir. Stratejik değerlendirmeye yürütme kurulu, yönetim kurulu, yetkili müdürler ve personel müdürü katılmaktadır. Yeni stratejiler geliştirildikten sonra gelecekte oluşturulabilecek stratejiler için maliyet hesaplamasında yürütme kurulu, yönetim kurulu, yetkili müdürler ve insan kaynakları müdürü aktif olarak katılmaktadır. Bu durum işletmelerin hem performans ölçümüne hem de değişim etkilerinin incelenmesi konularına çok önem verildiğinin bir göstergesi olarak kabul edilebilir.

Konaklama işletmelerine sunulan öneriler şunlardır:

- İşletmede görev yapan orta ve üst düzey tüm yöneticiler, küresel düşünüp yerel uygulamalı ve işletmeyi olduğu noktadan daha ileriye taşıyacak yeni vizyon ve misyon belirlemeli ayrıca bunu belirli periyotlarla yenileyip sürekli iyileştirme felsefesi ile devam ettirmelidir.

- Stratejik yönetim süreci evresi değerlendirmelerinde tüm üyelerin daha etkin katılımıyla ve çalışanların motivasyonunun arttırılması sağlanmalıdır.

- Tüm süreçte yer alan evrelerde değerlendirmeler yapılırken kişisel menfaatler yerine işletmenin menfaatleri düşünülerek etkili ve adil bir yöntem olan temel göstergeler daha aktif bir şekilde kullanılmalıdır.

- Konaklama işletmeleri özellikle maliyetlerin çok yüksek olduğu bazı alanlarda dış kaynak kullanımına gitmelidir.

- Finansal kapasitelerin yeterli olduğu için kısa dönemli maliyet liderliği stratejisi uygulanması düşünülebilir. 
- Turizm sektörü bir hizmet sektörüdür bu nedenle tüm kontrol evrelerinde gerekli hassasiyet gösterilmelidir. Çünkü üretim ve tüketim aynı anda gerçekleşmekte ve denetimin ani olması gerekmektedir.

- Her zaman aynı stratejiyi uygulamak yeterli olmayabilir. Bu nedenle alternatif stratejiler oluşturulmalıdır.

- Her zaman tek bir stratejiye bağlı kalmak hiç beklenmedik bir kriz durumuna karşı hazırlıksız olarak yakalanmasına neden olabilir. $\mathrm{Bu}$ nedenle mevcut durum sürekli kontrol edilmeli ve alternatif stratejilerle ilgili sürekli eğitimler uygulanmalıdır.

\section{KAYNAKÇA}

Akgemci, T.(2008). Stratejik yönetim. 2. Basım. Ankara:Gazi Kitabevi.

Çıkmak, S. (2012). İşletmelerde Stratejik Yönetim Sürecinin İncelenmesi Ve Yeniden Yapılandırılması : Bir Örnek Uygulama. Sakarya Üniversitesi Sosyal Bilimler Enstitüsü, Yüksek Lisans Tezi, Sakarya Dinçer, Ö.(2004). Stratejik yönetim işletme politikası. İstanbul: Beta Yayınevi. Eren E. (2005). Stratejik yönetim ve işletme politikaları, 7. Baskı, İstanbul: Beta Yayınları.

Espino-Rodriquez, T. F. ve Robaine, V. P., (2005). The Management Perception of the Strategic Outsourcing of Services:An Empirical Exemanition in the Hotel Sector. The Service Industries Journal, 25(5), 689-708.

Fache, W., (2000). Methodologies for Innovation and Improvement of Services in Tourism., Managing Service Quality, 10(6), 356-366.

Güçlü, N. (2003). Stratejik yönetim. Gazi Eğitim Fakültesi Dergisi 23(2),Ankara.

Güngör, S. ve Arslan, M., (2004). Turizm ve Rekreasyon Stratejileri İçin SWOT Analizi, Görsel Kalite Değerlendirmesi, Turizm Tesislerinin Beğenirliliği ve Turizm Tesisleri Durum Analizi Uygulamas. S.Ü. Ziraat Fakültesi Dergisi, 18(33), 68-72.

Kano, M., Drummond, S., Miller, C. ve Barclay, S.,(2001). Learning from others: Benchmarking in diverse tourism enterprises. Total Quality Management, 12(7\&8), 974-980. 
Kaya, İ. (2010). Konaklama işletmeciliğinde stratejik yönetim süreci: Kavramsal bir yaklaşım. KMÜ Sosyal ve Ekonomik Araştırmalar Dergisi 12(18): 27-35.

Kıngır, S., (2006). Bir hizmet işletmesi olarak beş yıldızlı otel işletmelerindeki yönetsel sorunlar. S.Ü. Sosyal Bilimler Enstitüsü Dergisi, 15, 457-481.

Kutlu, M.(2010). Stratejik yönetim bilgi sistemi (MIS), http:// www.merih.net/m2/str/stramis.htm (Erişim Tarihi: 05. 10.2017).

Ödemiş, M.(2014). Otel işletmelerinin stratejik yönetim ve araçlarını uygulama anlayışları üzerine bir araştırma. Gazi Üniversitesi Eğitim Bilimleri Enstitüsü, Yüksek Lisans Tezi, Ankara.

Özer M, A. (2015) İşletmelerde stratejinin önemi üzerine değerlendirmeler. International Journal Of Economic And Administrative Studies 7(14), 69-82

Özer, M. A.(2011). 21. YY'da yönetim ve yöneticiler. Ankara: Nobel Yayın. Şentürk, F. K.(2010). Otel İşletmelerinde Stratejik Yönetim Araçları Kullanımı Üzerine Bir Araştırma. Akdeniz Üniversitesi Sosyal Bilimler Enstitüsü, Yüksek Lisans Tezi, Antalya.

Şişman, A.,(2007). Otel işletmelerinde swot analizi. http://www.turizmdebusabah.com/haber_detay haberNo 29588 f otel_i\%C5\%9Fletmelerinde_swot_analizleri.htm, (Erişim Tarihi: 10.10.2017).

Ülgen, H. ve Mirze, M.(2013). İşletmelerde stratejik yönetim. İstanbul: Beta Yayınevi.

Uygur A., ve Bozkurt İ., (2017). Konaklama işletmelerinde stratejik yönetim sürecinin incelenmesi : NG Afyon örneği. Akademik Sosyal Araştırmalar Dergisi, 5(42), 1-19.

\section{Kaynakça Bilgisi / Citation Information}

Türk, M. ve Kara, E. (2017). Konaklama işletmelerinde stratejik yönetim süreci: yöneticiler üzerine bir araştırma. OPUS - Uluslararası Toplum Araştırmaları Dergisi, 7(13), 552-574. 